\title{
Comparison of the isotope hydrogeological features of thermal and cold karstic waters in the Denizli Basin (Turkey) and Buda Thermal Karst (Hungary)
}

\author{
István Fórizs \\ Institute for Geochemical Research \\ Hungarian Academy of Sciences, Budapest \\ Sándor Kele \\ Institute for Geochemical Research, \\ Hungarian Academy of Sciences, Budapest \\ József Deák \\ GWIS Ltd, Dunakeszi
}

\author{
Ali Gökgöz \\ Department of Geological Engineering \\ Pamukkale University, Denizli
Mehmet Özkul
Department of Geological Engineering,
Pamukkale University, Denizli \\ Mehmet Oruç Baykara, \\ Mehmet Cihat Alçiçek \\ Department of Geological Engineering, \\ Pamukkale University, Denizli
}

\begin{abstract}
The isotopic compositions of the Hungarian warm and cold water samples are spread in a wide range along the Global Meteoric Water Line (GMWL), which is a result of the significant change in the climate (mainly temperature) during infiltration (Last Glaciation and Holocene) and of the mixing process along the fault zone. The thermal karst water is isotopically lighter as it was infiltrated in a 7 to $9{ }^{\circ} \mathrm{C}$ cooler climate in the Ice Age. However, in the Denizli Basin isotopic composition of all of the thermal, lukewarm and cold waters varies in a relatively narrow range, with the exception of some warm waters whose $\mathrm{d} 18 \mathrm{O}$ values have been shifted as a result of water-rock interaction.

Isotope data prove that all the waters in the Denizli Basin infiltrated in the Holocene under more or less the same climate, so these waters are young indicating much shorter transit time from the recharge to the discharge areas because of faster flow under the surface or shorter path of the subsurface flow.
\end{abstract}

Key words: thermal water, stable oxygen and hydrogen isotopes, water age, water-rock interaction

\section{Introduction}

The importance of researches focussed on the sustainability of thermal water systems worldwide has increased recently. In the framework of a TurkishHungarian scientific cooperation several thermal and cold karst springs and wells and their carbonate deposits (travertines) have been studied both in the Denizli Basin (SW-Turkey) and in the Buda Thermal Karst system (Budapest, Hungary). Stable isotope and chemical methods have been applied beside the standard sedimentological, petrographical methods (optical microscope, SEM, $X R D$, etc.). This paper is restricted to the presentation and compar-

Address of corresponding author: I. Fórizs: H-1112 Budapest, Budaörsi út 45, Hungary e-mail: forizs@geochem.hu

Recedived: May 24, 2011; accepted: June 6, 2011 
ison of the stable hydrogen- and oxygen isotopic composition of water samples from the two study areas located under different climatic and tectonic conditions.

The Denizli Basin is a $70 \mathrm{~km}$ long and $50 \mathrm{~km}$ wide fault bounded NeogeneQuaternary depression located in the Western Anatolian Extensional Province, which is one of the most seismically active and rapidly extending regions (30-40 mm/year) in the world (Westaway 1993; Bozkurt 2001; Alçiçek et al. 2007; Alçiçek 2010) (Fig. 1B). The climate in the Denizli Basin is not uniform and mostly terrestrial with hot and dry summers and mild and rainy winters. The outflow temperature of the cold and thermal karst waters varies from $15^{\circ} \mathrm{C}$ to $70{ }^{\circ} \mathrm{C}$. The annual precipitation is $560 \mathrm{~mm}$.

The Buda Thermal Karst system (Hungary) is located at the boundary of uplifted carbonates and a sedimentary basin and serves as a discharge zone of the regional fluid flows.

Within this fault zone in the vicinity of the Danube more than 100 thermal springs are arising yielding totally about $40000 \mathrm{~m}^{3}$ per day of warm and lukewarm mineral water. Ascending thermal water (along faults) mix with cooler meteoric water producing the thermal springs and spas along the Danube with varying temperature. The climate in the Buda Hills area is continental with annual precipitation of $600-700 \mathrm{~mm}$. The outflow temperature of the cold and thermal karstic waters varies from $10{ }^{\circ} \mathrm{C}$ to $77^{\circ} \mathrm{C}$.
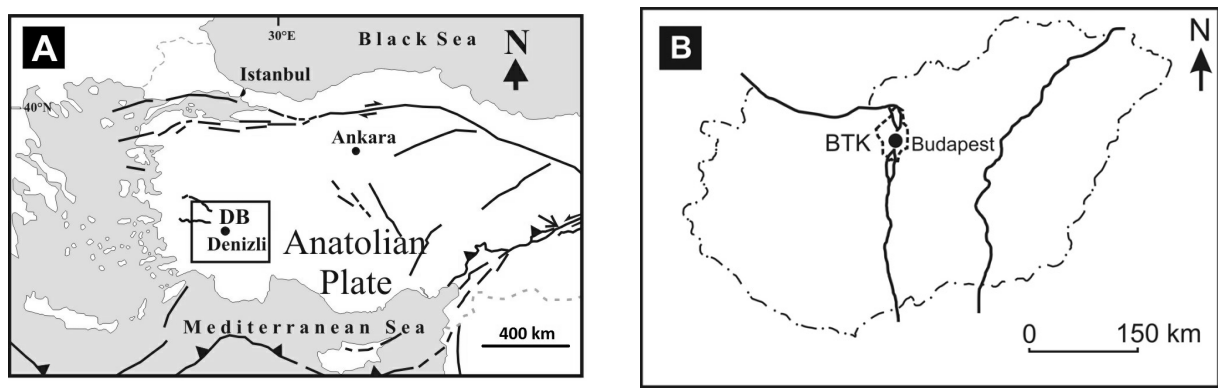

Fig. 1

Location of the study areas. A: Denizli Basin DB in Turkey modified after Uysal et al. 2009; B: Buda Thermal Karst BTK (Hungary)

\section{Results and discussion}

In Hungary, the study of thermal waters focussed on the Buda Hills (Buda Thermal Karst system), whereas in the Denizli Basin (SW-Turkey) on hot to lukewarm thermal waters and in both areas cold karstic waters were also investigated. These studies provided new and important information on the origin of waters and on the distribution of the water circulation systems in both investigated areas.

Thermal waters $\left(>50{ }^{\circ} \mathrm{C}\right)$ of Budapest and its neighbouring areas are isotopically significantly lighter than those of the cold karst waters (Fig. 2) and 


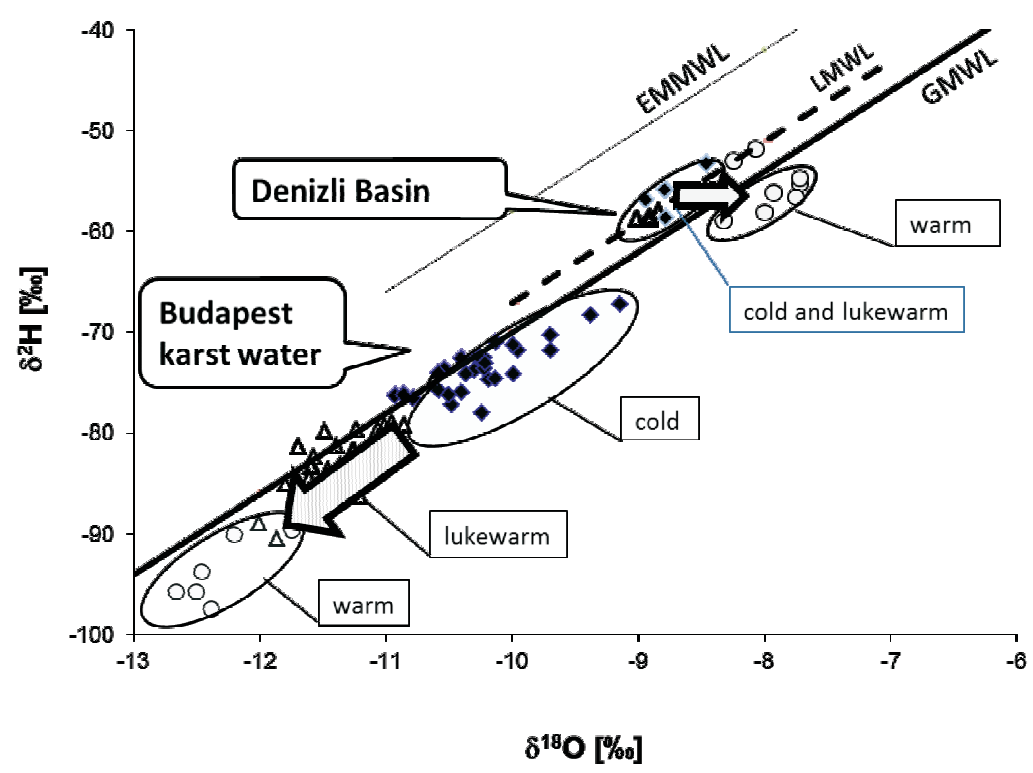

Fig. 2

Stable oxygen and hydrogen isotopic composition of the thermal and cold karst waters in the Denizli Basin (Turkey) and in the Budapest Thermal Karst Water system (Hungary). GMWL = Global Meteoric Water Line, LMWL = Local Meteoric Water Line of Denizli Basin (this work), EMMWL = Eastern Mediterranean Meteoric Water Line (Gat and Carmi 1970)

local precipitation of $\delta^{18} \mathrm{O}=-9.5 \%$ and $\delta^{2} \mathrm{H}=-65 \%$ (Deák 1979). "Altitude effect" can be excluded because the recharge area has only 300 to $500 \mathrm{~m}$ elevation so the possible reason of the lower $\delta^{18} \mathrm{O}$ and $\delta^{2} \mathrm{H}$ values should be a 7 to $9{ }^{\circ} \mathrm{C}$ colder climate at the time of infiltration than recent. These results refer to the Ice Age infiltration of warm water and are in good agreement with corrected ${ }^{14} \mathrm{C}$ ages of thermal waters as 15 to $25 \mathrm{ka}$ (Deák 1980). Following the flow path from the recharge to the discharge areas, karst water is continually becoming lighter reflecting the significant change in the mean annual air temperature during the infiltration period (from Holocene back to Ice Age). Additionally, later, on the discharge area (at the fault zone along the Danube River) the "old" warm waters are mixed up with younger (and colder) waters infiltrated during the last centuries. Accordingly, the isotopic compositions of subsurface waters of the Budapest karst system are spread in a wide range along the Global Meteoric Water Line following the direction of the arrow in Fig. 2 from cold to warm water.

However, in the Denizli Basin the isotopic composition of all karst water samples varies in a relatively narrow range (Fig. 2). Deuterium $\left({ }^{2} \mathrm{H}\right)$ contents of cold, lukewarm and warm waters are similar, suggesting that all the waters in the 
Denizli Basin infiltrated under more or less the same climate, probably during the Holocene. For some lukewarm and hot waters, what we have also studied in the Pamukkale and Karahayit areas, Simsek (2003) reported tritium contents around $4 \mathrm{TU}$, which indicates a very young, namely modern component infiltrated after the first thermonuclear bomb tests of 1952. These waters are certainly mixtures of hot, older component and a cold, (tritium-bearing) modern component, where the old component is younger than $10 \mathrm{ka}$ indicated by the stable isotopic composition The small variations in $\delta^{2} \mathrm{H}$ are caused mostly by the elevation effect, i.e. different flow systems have their recharge area located at different heights above sea level. Accepting these results, thermal waters are young (infiltrated in the last $10 \mathrm{ka}$ ) by stable isotope data, indicating much shorter transit time because of either faster flow or shorter path of the subsurface flow.

Some Turkish warm water samples fall below the GMWL (Fig. 2) because their $\delta^{18} \mathrm{O}$ values are shifted to more positive values. Usually this kind of $\delta^{18} \mathrm{O}$ shift is characteristic for hot waters, where during the rock-water interaction the $\delta^{18} \mathrm{O}$ value is changed to positive direction, but the $\delta^{2} \mathrm{H}$ value remained unaltered. Direction of this shift is presented by the arrow in Fig. 2.

The cold and lukewarm water samples of the Denizli Basin - comprising the majority of the studied waters in Fig. 2 - are above the GMWL and below the Eastern Mediterranean Meteoric Water Line (EMMWL, Gat and Carmi 1970), closer to the GMWL. This observation suggests a Local Meteoric Water Line for the Denizli Basin as $\delta^{2} \mathrm{H}=8^{*} \delta^{18} \mathrm{O}+13$, although in the future more data has to be used to refine this equation.

The Budapest samples plot just below the GMWL, which is characteristic for the present precipitation in the Carpathian Basin and nearby areas (Vodila et al. 2011; Vreca et al. 2006; Deák 2006). While the cold and tepid Turkish waters plot over the GMWL which is characteristic for the Eastern Mediterranean territories. Gat and Carmi (1970) reported $\delta^{2} \mathrm{H}=8^{*} \delta^{18} \mathrm{O}+22 \%$ as the Eastern Mediterranean Meteoric Water Line (EMMWL). The very high intercept of $22 \%$ o in the above equation is caused by the component of evaporation from the Mediterranean Sea, because the relative humidity over this sea is less than global average $(85 \%)$. In the case of Denizli Basin this intercept is around $13 \%$ indicating smaller effect of the Mediterranean Sea here than in the Levant.

\section{Acknowledgements}

This study was performed in the frame of a Turkish-Hungarian joint project supported by The Scientific and Technical Research Council of Turkey (TÜBITAK, Project Number: 106 Y 207) and the National Office for Research and Technology (NTKH, Hungary, project number: TR-10/2006). The sampling in the area of Budapest and the related stable isotope analyses have been financed by the Hungarian Scientific Research Fund (project OTKA K 60921). 


\section{References}

Alçiçek, H. 2010: Stratigraphic correlation of the Neogene basins in southwestern Anatolia: regional palaeogeographical, palaeoclimatic and tectonic implications. - Palaeogeography, Palaeoclimatology, Palaeoecology, 291, pp. 297-318.

Alçiçek, H., B. Varol, M. Özkul 2007: Sedimentary facies, depositional environments and palaeogeographic evolution of the Neogen Denizli Basin, SW Anatolia, Turkey. - Sedimentary Geology, 202, pp. 596-637.

Bozkurt, E. 2001: Neotectonics of Turkey - a synthesis. - Geodinamica Acta, 14, pp. 3-30.

Deák, J. 1979: Environmental isotopes and water chemical studies for groundwater research in Hungary. - Isotope Hydrology, 1978. pp. 221-249., IAEA, Vienna.

Deák, J. 1980: Radiocarbon dating of the thermal waters in the Budapest area. - Zentralinstitut für Isotopen, Mitteilungen, 30, pp. 257-266, Leipzig.

Deák, J. 2006: A Duna-Tisza köze rétegviz áramlási rendszerének izotóp hidrológiai vizsgálata (Isotope hydrological study of the groundwater flow regime of Danube-Tisza region). - PhD thesis Eötvös Loránd University, Budapest, 112 p. (In Hungarian.)

Gat, J.R., I. Carmi 1970: Evolution in the isotopic composition of atmospheric waters in the Mediterranean Sea area. - Journal of Geophysical Research, 75, pp. 3039-3048.

Simsek, S. 2003: Hydrogeological and isotopic survey of geothermal fields in the Büyük Menderes graben, Turkey. - Geothermics, 32, pp. 669-678.

Uysal, T., Y. Feng, J. Zhao, V. Isik, P. Nuriel, S.D. Golding 2009: Hydrothermal $\mathrm{CO}_{2}$ degassing in seismically active zones during the late Quaternary. - Chemical Geology, 265, pp. 442-454

Vodila, G., L. Palcsu, I. Futó, Zs. Szántó 2011: A 9-year record of stable isotope ratios of precipitation in Eastern Hungary: Implications on isotope hydrology and regional palaeoclimatology. Journal of Hydrology, 400/1-2, pp. 144-153.

Vreca, P, I. Krajcar-Bronic, N. Horvatincic, J. Barešic 2006: Isotopic characteristics of precipitation in Slovenia and Croatia: Comparison of continental and maritime stations. - Journal of Hydrology, 330/3-4, pp. 457-469.

Westaway, R. 1993: Neogene evolution of the Denizli region of western Turkey. - Journal of Structural Geology, 15, pp. 37-53. 